\title{
Pengaruh Inflasi, Kurs, Suku Bunga, dan Harga Minyak Dunia Terhadap Indeks Harga Saham Industri Pertambangan di Bursa Efek Indonesia Periode 2012-2015
}

\author{
Yulia Istia Ningsih, Muthmainnah \\ Dosen Fakultas Ekonomi Jurusn D3 Akuntansi Sekolah Tinggi Ilmu Ekonomi Graha Karya \\ E-mail: yuliastiegk@gmail.com
}

\begin{abstract}
This study aims to determine how the influence of inflation, exchange rates, interest rates, and world oil prices on the mining industry stock price index in the period 2012-2015. The object in the 2012-2015 research period is mining companies on the Indonesia Stock Exchange. The population used in this study were 31 mining companies and was based on a purposive sampling method which produced a sample of 11 companies. The dependent variable is represented by the mining industry stock price index, while the independent variables in this study are inflation, exchange rates, interest rates, and world oil prices. Partially the results of this study indicate that during the 2012-2015 period the variable exchange rates and world oil prices affected the mining industry's stock price index, while inflation and interest rates did not affect the stock price index mining industry. Simultaneously shows the influence of independent variables on the mining industry stock price index.
\end{abstract}

Keywords: Stock Price Index; Inflation; Exchange Rates; Interest Rates; World Oil Prices

DOI: 10.33087 /ekonomis.v3i1.52

\section{PENDAHULUAN}

Dalam melakukan investasi di pasar modal para analisis dan investor dapat melakukan pendekatan investasi yang secara garis besar dapat dibedakan menjadi dua pendekatan yaitu analisis teknikal dan analisis fundamental. Analisis teknikal merupakan upaya untuk memperkirakan harga saham dengan mengamati perubahan harga saham tersebut di waktu lampau (Adisetiawan, 2018). Sedangkan analisis fundamental merupakan teknik analisis saham yang mempelajari tentang keuangan mendasar dan fakta ekonomi dari perusahaan sebagai langkah penilaian nilai saham perusahaan (Adisetiawan, 2017a). Analisis Fundamental berlandaskan kepercayaan bahwa nilai suatu saham sangat dipengaruhi oleh kinerja perusahaan yang menerbitkan saham tersebut. Analisis fundamental pada dasarnya adalah melakukan analisis historis atas kekuatan keuangan dari suatu perusahaan, dimana proses ini sering juga disebut sebagai analisis perusahaan (company analysis). Analisis fundamental mencoba memperkirakan harga saham di masa yang akan datang dengan mengestimasi nilai faktor-faktor fundamental yang mempengaruhi harga saham di masa yang akan datang dan menerapkan hubungan variabel-variabel tersebut sehingga diperoleh taksiran harga saham. Jika prospek suatu perusahaan publik sangat kuat dan baik, maka harga saham perusahaan tersebut diperkirakan meningkat pula. (Adisetiawan, 2011)

Adanya keadaan bahwa harga saham yang sangat berfluktuatif, maka investor perlu untuk meprediksi fluktuasi yang akan terjadi dengan suatu ukuran kinerja yang dapat menjelaskan nilai perusahaan maupun faktor-faktor fundamental lain seperti kondisi ekonomi makro. Lingkungan ekonomi makro merupakan lingkungan yang mempengaruhi operasi perusahaan sehari-hari. Kemampuan investor dalam memahami dan meramalkan kondisi ekonomi makro di masa datang akan sangat berguna dalam pembuatan keputusan investasi yang menguntungkan (Adisetiawan dan Surono, 2011). Untuk itu, seorang investor harus mempertimbangkan beberapa indikator ekonomi makro yang bisa membantu investor dalam membuat keputusan investasinya. Indikator ekonomi makro yang seringkali dihubungkan dengan pasar modal adalah fluktuasi tingkat bunga, inflasi, dan kurs rupiah. Perekonomian dunia, nilai mata uang tidak pernah ada yang stabil. Disisi lain, harga-harga barang dan jasa cenderung mengalami peningkatan. Keadaan ini akan mengakibatkan daya beli mata uang tersebut menjadi turun yang mengakibatkan terjadinya inflasi. Dengan semakin meningginya angka inflasi maka perekonomian akan memburuk, sehingga hal ini akan berdampak turunnya keuntungan suatu perusahaan, yang mengakibatkan pergerakan harga saham (efek ekuitas) menjadi kurang kompetitif (Adisetiawan, 2017b).

Oleh karena itu kebijakan pemerintah untuk mengontrol laju inflasi menjadi hal yang sangat penting. Salah satunya adalah dengan melakukan penentuan tarif suku bunga di pasar keuangan. Suku bunga dapat dijadikan sebagai alat moneter dalam rangka mengendalikan penawaran dan permintaan uang yang beredar dalam suatu sistem perekonomian. Pada saat 
permintaan uang terlalu tinggi, sirkulasi uang di masyarakat terlalu besar, maka pemerintah dapat menaikkan suku bunga, agar penawaran uang meningkat dan permintaan uang turun. Dan sebaliknya pemerintah dapat menurunkan suku bunga untuk memberikan dukungan dan mempercepat pertumbuhan di sektor ekonomi dan industri, sehingga mendorong atau meningkatkan produksi menjadi lebih tinggi. Dengan adanya peningkatan produksi tersebut diharapkan mampu menurunkan laju inflasi dan menaikkan keuntungan perusahaan, yang berdampak positif pada perkembangan pasar modal (Adisetiawan, 2017b)

Di Indonesia energi juga memegang salah satu peran penting dalam perekonomian Indonesia. Hal ini dilatarbelakangi bahwa di Bursa Efek Indonesia, nilai kapitalisasi perusahaan tambang yang tercatat di IHSG mencapai 15,7\% (www.idx.co.id). Selain itu berdasarkan data Bursa Efek Indonesia (BEI) per Desember 2015, transaksi perdagangan saham didominasi oleh sektor pertambangan sekitar 22,2\%. Hal ini mengakibatkan kenaikan harga minyak dunia akan mendorong kenaikan harga saham perusahaan tambang. Selain Inflasi, suku bunga dan harga minyak dunia, variabel lain adalah nilai tukar (kurs). Nilai tukar mencerminkan keseimbangan permintaan dan penawaran terhadap mata uang dalam negeri maupun mata uang asing \$US. Merosotnya nilai tukar rupiah merefleksikan menurunnya permintaan masyarakat internasional terhadap mata uang rupiah karena menurunnya peran perekonomian nasional atau karena meningkatnya permintaan mata uang asing \$US oleh masyarakat karena perannya sebagai alat pembayaran internasional. Kinerja uang khususnya pasar luar negeri diukur melalui kurs rupiah, terutama mata uang dolar AS (Adisetiawan, 2017a). Semakin menguat kurs rupiah sampai batas tertentu berarti menggambarkan kinerja di pasar uang semakin menunjukkan perbaikan. Sebagai dampak meningkatnya laju inflasi maka nilai tukar mata uang domestik semakin melemah terhadap mata uang asing, hal ini mengakibatkan harga saham akan mengalami penurunan, dan investasi di pasar modal menjadi kurang diminati (Adisetiawan, 2018). Tujuan penelitian ini adalah Untuk mengetahui apakah inflasi, kurs, suku bunga dan harga minyak dunia secara simultan dan parsial berpengaruh terhadap harga saham pada indutri pertambangan yang terdaftar di Bursa Efek Indonesia periode 2012-2015.

\section{Tinjauan Pustaka \\ Hubungan antara variabel Independen terhadap variabel Dependen Inflasi terhadap Harga Saham}

Menurut Keynes dalam Adisetiawan (2017b), inflasi terjadi karena masyarakat menginginkan barang dan jasa yang lebih besar daripada yang mampu disediakan oleh masyarakat itu sendiri. Proses inflasi menurut kelompok ini adalah proses perebutan bagian rejeki diantara kelompok-kelompok sosial yang menginginkan bagian yang lebih besar dari apa yang mampu disediakan oleh masyarakat.

Teori strukturalis memberikan titik tekan pada ketegaran atau infleksibilitas dari struktur perekonomian negara-negara berkembang. Faktor strukturalis inilah yang menyebabkan perekonomian negara sedang berkembang berjalan sangat lambat dalam jangka panjang. Teori ini disebut inflasi jangka panjang. Menurut teori ini ada dua faktor utama yang dapat menimbulkan inflasi. Pertama, ketidakelastisan penerimaan ekspor, yaitu pertumbuhan nilai ekspor yang lamban dibanding dengan pertumbuhan sector-sektor lain. Hal ini disebabkan dua faktor utama yaitu : Jenis barang ekspor yang kurang responsif terhadap kenaikan harga dan nilai tukar barang ekspor yang semakin memburuk. Kedua, ketidakelastisan produksi bahan makanan di dalam negeri. Dalam hal ini laju pertumbuhan bahan makanan di dalam negeri tidak secepat laju pertumbuhan penduduk dan laju pendapatan perkapita. Akibat dari ini terjadi kenaikan harga barang lainnya, karena inflasi berpengaruhi terhadap tingkat investasi, maka aktivitas perdagangan di bursa saham akan terpengaruhi. Aktifitas perdagangan saham akan mempengaruhi kemungkinan perolehan keuntungan. Dengan demikian inflasi berpengaruh terhadap aktifitas di pasar saham. 
Pengaruh Inflasi, Kurs, Suku Bunga, dan Harga Minyak Dunia Terhadap Indeks Harga Saham Industri Pertambangan di Bursa Efek Indonesia Periode 20122015

\section{Kurs mata uang asing terhadap Harga Saham}

Kenaikan harga valuta asing disebut depresiasi atas mata uang dalam negeri. Mata uang asing menjadi lebih mahal, ini berarti nilai relatif mata uang dalam negeri merosot. Turunnya harga valuta asing disebut apresiasi mata uang dalam negeri. Mata uang asing menjadi lebih murah, ini berarti nilai relatif mata uang dalam negeri meningkat. Perubahan nilai tukar valuta asing disebabkan karena adanya perubahan permintaan atau penawaran dalam bursa valuta asing (hukum penawaran dan permintaan). Banyak sebab yang melatarbelakangi perubahan ini, seperti: Neraca ekspor impor, aliran modal, perubahan struktur, neraca perdagangan dan lainlain. Kurs rupiah dengan kurs mata uang asing akan mempengaruhi harga saham emiten. Hal ini bisa dijelaskan sebagai berikut: kurs rupiah akan mempengaruhi penjualan perusahaan (terutama untuk emiten yang berorientasi bisnis ekspor), Cost Of Good Sold (mempengaruhi pembelian bahan baku apabila diperoleh dari impor), dan rugi kurs. Khusus untuk rugi kurs, terutama bagi perusahaan yang memiliki kewajiban dalam mata uang asing, akan sangat terpengaruh oleh depresiasi maupun apresiasi rupiah. Menurunnya nilai tukar rupiah terhadap mata uang asing (dolar amerika) berdampak terhadap meningkatnya biaya impor bahan baku dan peralatan yang dibutuhkan perusahaan sehingga mengakibatkan meningkatnya biaya produksi, atau dengan kata lain melemahnya nilai tukar rupiah terhadap US Dollar memiliki pengaruh negatif terhadap ekonomi nasional yang pada akhirnya menurunkan kinerja saham di pasar saham. (Adisetiawan, 2014)

\section{Suku Bunga terhadap Harga Saham}

Kebijakan bunga rendah akan mendorong masyarakat untuk memilih investasi dan konsumsinya daripada menabung, sebaliknya kebijakan meningkatkan suku bunga simpanan akan menyebabkan masyarakat akan lebih senang menabung daripada melakukan investasi atau konsumsi. Dari sisi perusahaan, Weston dan Brigham (1998) mengatakan bahwa suku bunga mempengaruhi laba perusahaan dengan dua cara yaitu: (1) karena bunga merupakan biaya, maka makin tinggi tingkat suku bunga makin rendah laba perusahaan apabila hal-hal lain dianggap konstan; dan (2) suku bunga mempengaruhi tingkat aktifitas ekonomi dan karena itu mempengaruhi laba perusahaan. (Adisetiawan, 2012)

Suku bunga tidak diragukan lagi mempengaruhi harga saham karena pengaruhnya terhadap biaya dan modal. Berdasarkan hal tersebut maka hubungan antara suku bunga deposito dengan harga saham adalah negatif.

\section{Harga Minyak Dunia terhadap Harga Saham}

Harga minyak Brent merupakan campuran dari 15 jenis minyak mentah yang dihasilkan oleh 15 ladang minyak yang berbeda di Laut Utara. Kualitas minyak mentah Brent tidak sebaik minyak mentah WTI, meskipun begitu masih tetap bagus untuk disuling menjadi bahan bakar. Harga minyak mentah Brent menjadi patokan di Eropa dan Afrika. Harga minyak Brent lebih rendah sekitar satu hingga dua dolar dari harga minyak WTI, tetapi lebih tinggi sekitar empat dolar dari harga minyak OPEC (en.wikipedia.org). Harga minyak OPEC merupakan harga minyak campuran dari negara-negara yang tergabung dalam OPEC, seperti Algeria, Indonesia, Nigeria, Saudi Arabia, Dubai, Venezuela, dan Mexico. OPEC menggunakan harga ini untuk mengawasi kondisi pasar minyak dunia. Harga minyak OPEC lebih rendah karena minyak dari beberapa negara anggota OPEC memiliki kadar belerang yang cukup tinggi sehingga lebih susah untuk dijadikan sebagai bahan bakar (www.opec.org).

Beberapa hal yang mempengaruhi harga minyak dunia antara lain (useconomy.about.com): (1) penawaran minyak dunia, terutama kuota suplai yang ditentukan oleh OPEC; (2) cadangan minyak Amerika Serikat, terutama yang terdapat di kilang-kilang minyak Amerika Serikat dan yang tersimpan dalam cadangan minyak strategis; dan (3) permintaan minyak dunia, ketika musim panas, permintaan minyak diperkirakan dari perkiraan jumlah permintaan oleh maskapai penerbangan untuk perjalanan wisatawan. 
Pengaruh Inflasi, Kurs, Suku Bunga, dan Harga Minyak Dunia Terhadap Indeks Harga Saham Industri Pertambangan di Bursa Efek Indonesia Periode 20122015

Sedangkan ketika musim dingin, diramalkan dari ramalan cuaca yang digunakan untuk memperkirakan permintaan potensial minyak untuk penghangat ruangan.

Kenaikan harga minyak dunia bisa memberikan memberikan dampak berbeda pada setiap harga saham, yaitu harga saham dari perusahaan yang bergerak dibidang pertambangan dan perusahaan yang bergerak diluar bidang pertambangan. Pada perusahaan non pertambangan, kenaikan harga minyak bisa membawa dampak negatif karena akan mengakibatkan kenaikan biaya produksi dan secara tidak langsung akan menurunkan harga saham. Sedangkan pada perusahaan pertambangan, kenaikan harga minyak membawa dampak positif pada penerimaan yang akan diperoleh dan tentunya harga saham juga akan meningkat. (Adisetiawan, 2014)

\section{Hipotesis}

Hipotesis dalam penelitian ini adalah diduga variabel inflasi, kurs, suku bunga, dan harga minyak dunia berpengaruh secara simultan dan parsial terhadap indeks harga saham Industri Pertambangan yang terdaftar di Bursa Efek Indonesia Periode 2012-2015

\section{METODE}

Populasi penelitian yang dilakukan ini adalah pada seluruh perusahaan pertambangan di Bursa Efek Indonesia selama periode 2012-2015, yaitu berjumlah 31 perusahaan. Metode penarikan sampel ini dilakukan dengan metode Purposive Sampling, yaitu suatu metode penarikan sampel di mana pemilihan sampel berdasarkan tujuan peneliti dan tidak secara acak dan mempunyai data-data yang dibutuhkan dalam penelitian (Sugiyono, 2007). Kriteria yang ditetapkan adalah sebagai berikut: (1) perusahaan pertambangan yang telah dan masih tercatat (listed) di Bursa Efek Indonesia pada Januari 2012-Desember 2015 secara berturut-turut; (2) perdagangan saham emiten tidak pernah digantung selama lebih dari satu bulan; (3) perusahaan pertambangan yang membagikan dividen periode Januari 2012-Desember 2015; dan (4) data perusahaan yang dibutuhkan tersedia. Berdasarkan kriteria yang telah ditetapkan di atas, maka diperoleh 11 perusahaan yang menjadi sampel dalam penelitian ini, yakni Adaro Energy (ADRO), Aneka Tambang (ANTM), Bumi Resources (BUMI), Citra Mineral Investindo (CITA), Elnusa (ELSA), Indo Tambangraya Megah (ITMG), Medco Energy International (MEDC), Perdana Karya Perkasa (PKPK), Tambang Batubara Bukit Asam (PTBA), Petrosea (PTRO), dan Timah (TINS).

Data yang dibutuhkan adalah data sekunder. Data sekunder adalah data yang diperoleh dari pihak lain dalam bentuk yang sudah jadi dan dipublikasikan untuk umum. Data sekunder berupa : (1) harga saham bulanan selama periode 2012-2015diperoleh dari BEI monthly Statistic Report periode 2012-2015 dan finance.yahoo.com periode Januari 2012-Desember 2015; dan (2) variabel makro meliputi 4 variabel makro ekonomi di Indonesia, yaitu Inflasi, Kurs, Suku bunga SBI, dan Harga Minyak Dunia selama periode 2012-2015 diperoleh dari website Bank Indonesia, Biro Pusat Statistik, finance.yahoo.com, website petrosea periode 2012-2015.

\section{Metode Analisis Data dan Pengujian Hipotesis}

Untuk mencapai tujuan penelitian maka digunakan analisis regresi berganda untuk memperoleh gambaran yang menyeluruh mengenai hubungan antara variabel dependen dengan variabel independen. Model penelitian yang digunakan dalam penelitian ini yaitu :

$\mathbf{Y}=\mathbf{a}+\mathbf{b} 1 \mathbf{X}_{1}+\mathbf{b} 2 \mathbf{X}_{2}+\mathbf{b} 3 \mathbf{X}_{3}+\mathbf{b} 4 \mathbf{X}_{4}+\mathbf{e}$

$\mathrm{Y}=$ harga saham; $\mathrm{a}=$ konstanta; $\mathrm{b} 1, \mathrm{~b} 2, \mathrm{~b} 3, \mathrm{~b} 4=$ koefien regresi; $\mathrm{X}_{1}=$ Inflasi; $\mathrm{X}_{2}=$ Kurs; $\mathrm{X}_{3}=$ Suku Bunga; $\mathrm{X}_{4}=$ Harga Minyak Dunia; e = standar error

\section{Pengujian Asumsi Klasik}

Dalam penggunaan persamaan regresi terdapat beberapa asumsi- asumsi dasar yang harus dipenuhi terlebih dahulu. Asumsi-asumsi tersebut adalah sebagai berikut: (Sugiyono, 2007) 
Pengaruh Inflasi, Kurs, Suku Bunga, dan Harga Minyak Dunia Terhadap Indeks Harga Saham Industri Pertambangan di Bursa Efek Indonesia Periode 20122015

a. Uji Normalitas data, pengujian normalitas dalam penelitian ini dengan menggunakan Kolmogorov-Smirnov Test. Apabila dalam perhitungan diperoleh nilai signifikan lebih dari 0.05, maka data tersebut berdistribusi normal. Sebaliknya, jika nilai signifikan dibawah 0.05, maka data tersebut tidak berdistribusi normal.

b. Uji Heteroskedastisitas, masalah heteroskedastisitas dalam model persamaan regresi ini dilakukan dengan metode Glejser Test, yaitu dengan cara meregresikan nilai absolute residual terhadap variabel independen, sehingga dapat diketahui ada tidaknya derajat kepercayaan 5\%. Jika nilai signifikansi > 0.05, maka tidak terjadi heteroskedastisitas. Sebaliknya, jika nilai signifikansi $<0.05$, maka terjadi heteroskedastisitas.

c. Uji Multikolinearitas, uji ini dilakukan dengan melihat tolerance value atau variance inflation factor (VIF). Batas dari tolerance value adalah 0.10 atau batas variance inflation factor (VIF) adalah 10. Jika tolerance value diatas 0.10 atau nilai Variance Inflation Factor (VIF) dibawah 10, maka tidak terjadi multikolinearitas. Sebaliknya, jika tolerance value dibawah 0.10 atau nilai Variance Inflation Factor (VIF) diatas 10, maka terjadi multikolinearitas.

d. Autokorelasi, pendeteksian gejala ini dilakukan dengan menggunakan Uji Statistik DurbinWatson, yaitu dengan membandingkan angka Durbin-Watson dengan nilai kritisnya. Pengambilan keputusan ada tidaknya autokorelasi uji Durbin-Watson dapat dijelaskan melalui Tabel 1 sebagai berikut :

Tabel 1. Pengambilan keputusan Autokorelasi Uji Durbin-Watson

\begin{tabular}{lll}
\hline No & Nilai & Keterangan \\
\hline 1 & $<1.10$ & Ada Autokorelasi \\
2 & $1.10-1.54$ & Tidak ada kesimpulan \\
3 & $1.55-2.45$ & Tidak ada autokorelasi \\
4 & $2.46-2.90$ & Tidak ada kesimpulan \\
5 & $>2.90$ & Ada autokorelasi \\
\hline
\end{tabular}

\section{Pengujian Hipotesis}

a) Menguji hipotesis secara simultan (Uji statistik F), menurut Sugiyono (2007) uji statistik F pada dasarnya menunjukkan apakah semua variabel bebas yang dimaksudkan dalam model mempunyai pengaruh secara simultan terhadap variabel dependen. Pengujian dilakukan dengan menggunakan signifikansi level $0.05(5 \%)$. Ketentuan penerimaan atau penolakan hipotesis adalah sebagai berikut :

a. Jika nilai signifikan > 0.05 maka hipotesis ditolak (koefisien regresi tidak signifkan). Ini berarti secara simultan variabel dependen tersebut tidak mempunyai pengaruh yang signifikan terhadap variabel dependen.

b. Jika nilai signifikan < 0.05, maka hipotesis diterima. Ini berarti secara simultan variabel independen tersebut mempunyai pengaruh yang signifikan terhadap variabel dependen.

b) Uji Statistik t (Uji Parsial), tujuan pengujian ini adalah untuk mengetahui seberapa jauh pengaruh variabel independen secara individual terhadap variabel dependen. Membandingkan antara $\mathrm{t}$ value dengan tingkat signifikansi 0.05, maka dapat ditentukan apakah Hipotesis ditolak apabila t value $>0.05$ dan apabila nilai signifikansi $<0.05$ maka hipotesis diterima yang artinya variabel tersebut secara individu berpengaruh terhadap variabel dependen.

c) Koefisien Determinasi, koefisien determinasi $\mathrm{R}^{2}$ pada intinya mengukur seberapa jauh kemampuan model dalam menerangkan variabel-variabel dependen. Nilai koefisien determinasi berada di antara 0 dan 1 . Nilai $R^{2}$ kecil berarti kemampuan variabel-variabel independen dalam menjelaskan variabel dependen amat terbatas. Nilai yang mendekati 1 berarti variabel-variabel independen memberikan hampir semua informasi yang dibutuhkan untuk memprediksi variasi variabel dependen. 
HASIL

Uji Asumsi Klasik

Uji Normalitas

Tabel 2. Uji Statisitik Non Parametrik Kolmogorov-Smirnov Test

\begin{tabular}{|ll|r|r|r|r|r|}
\hline & & \multicolumn{1}{|c|}{$\mathrm{Y}$} & $\mathrm{X} 1$ & $\mathrm{X} 2$ & \multicolumn{1}{c|}{$\mathrm{X} 3$} & $\mathrm{X} 4$ \\
\hline $\mathrm{N}$ & & 44 & 44 & 44 & 44 & 44 \\
Normal Parametersa & Mean & -.004620 & -.000489 & -.001400 & -.037634 & -.036643 \\
& Std. Deviation & .9740752 & .9772577 & .9776044 & .9484215 & .9282373 \\
Most Extreme Differences & Absolute & .153 & .312 & .167 & .276 & .089 \\
& Positive & .153 & .312 & .167 & .276 & .089 \\
& Negative & -.146 & -.205 & -.109 & -.116 & -.072 \\
& & 1.025 & 2.092 & 1.119 & 1.851 & .599 \\
Kolmogorov-Smirnov Z & & .244 & .252 & .163 & .072 & .866 \\
\hline
\end{tabular}

Sumber : Data diolah

Berdasarkan hasil output spss 16.0, distribusi data dinyatakan normal karena signifikannya menunjukkan hasil diatas 5\%. Dengan demikian dapat disimpulkan bahwa masing-masing variabel bebas di dalam model regresi ini distribusi datanya normal.

\section{Uji Heterokesdastisitas}

Tabel 3. Coefficients

\begin{tabular}{|c|c|c|c|c|c|c|}
\hline \multirow[b]{2}{*}{ Model } & \multicolumn{2}{|c|}{ Unstandardized Coefficients } & \multirow{2}{*}{\multicolumn{2}{|c|}{$\frac{\text { Standardized Coefficients }}{\text { Beta }}$}} & \multirow[b]{2}{*}{$\mathrm{t}$} & \multirow[b]{2}{*}{ Sig. } \\
\hline & $\mathrm{B}$ & Std. Error & & & & \\
\hline (Constant) & .608 & .059 & & & 10.387 & .000 \\
\hline $\mathrm{X} 1$ & .136 & .089 & & $.31 \xi$ & 1.533 & .133 \\
\hline $\mathrm{X} 2$ & .210 & .077 & & .49 & 2.750 & .099 \\
\hline $\mathrm{X} 3$ & -.085 & .072 & & -.19 & -1.184 & .244 \\
\hline $\mathrm{X} 4$ & -.037 & .073 & & -.08 & -.516 & .609 \\
\hline
\end{tabular}

Sumber: data olahan

Tabel 3 menunjukkan bahwa, dapat dilihat jika nilai signifikansi dari variabel tersebut > 0.05, variabel di atas diketahui tidak memiliki hubungan antara variabel bebas dengan nilai mutlak residual sehingga menunjukkan tidak adanya masalah heteroskesdasitas dalam model regresi.

\section{Uji Multikolinearitas}

Tabe1 4. Nilai Tolerance dan VIF

\begin{tabular}{|l|r|r|}
\hline \multirow{2}{*}{ Model } & \multicolumn{2}{|c|}{ Collinearity Statistics } \\
\cline { 2 - 3 } & Tolerance & \multicolumn{1}{|c|}{ VIF } \\
\hline (Constant) & .463 & 2.159 \\
X1 & .624 & 1.602 \\
X2 & .757 & 1.321 \\
X3 & .771 & 1.297 \\
X4 & & \\
\hline
\end{tabular}

Sumber : Data diolah 
Berdasarkan tabel diatas terlihat bahwa tidak ada variabel bebas yang memiliki nilai VIF yang besar dari 10. Hal ini berarti tidak ada korelasi antar variabel bebas, sehingga dapat disimpulkan bahwa data bebas dari masalah multikolinearitas.

\section{Uji Autokorelasi}

Tabel 5. Hasil Uji Autokorelasi

\begin{tabular}{|l|lr|}
\hline Model & Durbin-Watson \\
\hline 1 & & 1.641 \\
\hline
\end{tabular}

Sumber : Data diolah

Model regresi yang diperoleh dalam penelitian ini memiliki nilai statistik Durbin-Watson $\mathrm{d}=1.641$, hal ini menunjukkan bahwa tidak adanya autokorelasi karena berdasarkan kriteria Durbin-Watson nilai 1.641 berada pada range antara 1.55-2.64, maka hal ini berarti tidak ada masalah autokorelasi data dalam penelitian ini.

\section{Hasil Analisis Regresi Berganda}

Persamaan regresi berganda dengan menggunakan output SPSS dapat dilakukan dengan menginterpretasikan angka-angka yang termuat dalam Tabel 3

\section{$\mathbf{Y}=0.016+0.044 X_{1}+0.576 X_{2}-0.113 X_{3}+0.692 X_{4}$}

Persamaan regresi diatas mempunyai makna sebagai berikut :

1. Koefisien regresi untuk variabel $\mathrm{X}_{1}$ yaitu variabel inflasi sebesar 0.044. Nilai koefisien tersebut menunjukkan bahwa jika inflasi naik $1 \%$ maka indeks harga saham akan naik sebesar 0.044

2. Koefisien regresi untuk variabel $\mathrm{X}_{2}$ yaitu variabel kurs sebesar -0.131. Nilai koefisien tersebut menunjukkan bahwa jika kurs naik $1 \%$ maka indeks harga saham akan naik sebesar 0.576.

3. Koefisien regresi untuk variabel $\mathrm{X}_{3}$ yaitu variabel suku bunga sebesar -0.113 Nilai koefisien tersebut menunjukkan bahwa jika suku bunga naik $1 \%$ maka indeks harga saham akan turun sebesar -0.113 .

4. Koefisien regresi untuk variabel $\mathrm{X}_{4}$ yaitu variabel harga minyak dunia sebesar 0.692. Nilai koefisien tersebut menunjukkan bahwa jika Ukuran Perusahaan naik $1 \%$ maka indeks harga saham akan naik sebesar 0.692 .

\section{Pengujian Statistik \\ Uji $F$}

Tabel 6. ANOVA

\begin{tabular}{|c|c|c|c|c|c|c|}
\hline & Model & Sum of Squares & Df & Mean Square & $\mathrm{F}$ & Sig. \\
\hline \multirow[t]{3}{*}{1} & Regression & 17.287 & 5 & \multirow{3}{*}{$\begin{array}{r}3.457 \\
.627\end{array}$} & \multirow[t]{3}{*}{5.512} & \multirow[t]{3}{*}{$.001^{a}$} \\
\hline & Residual & 24.461 & 39 & & & \\
\hline & Total & 41.748 & 44 & & & \\
\hline
\end{tabular}

Sumber : Data diolah

Berdasarkan Tabel 6 dapat dibandingkan bahwa nilai $p$ value (0.001a) <0.05 maka H0 ditolak dan Ha diterima, berarti secara bersama-sama variabel Inflasi, Kurs, Suku Bunga, dan Harga Minyak Dunia berpengaruh terhadap Indeks Harga Saham Industri Pertambangan.

\section{Uji t}

Berdasarkan Tabel 3 dapat dijelaskan bahwa standardized coefficients variabel Inflasi sebesar 0.044 untuk hasil uji t-hitung sebesar 0.246. Nilai signifikansinya sebesar 0.807 dan 
Pengaruh Inflasi, Kurs, Suku Bunga, dan Harga Minyak Dunia Terhadap Indeks Harga Saham Industri Pertambangan di Bursa Efek Indonesia Periode 20122015

angka ini lebih dari 0.05, ini menunjukkan bahwa tidak signifikansi dari variabel Inflasi terhadap Indeks Harga Saham Industri Pertambangan. Kesimpulannya Inflasi tidak berpengaruh terhadap Indeks Harga Saham Industri Pertambangan. Untuk variabel penelitian Kurs menunjukkan bahwa Leverage mempunyai t-hitung sebesar 0.576 dengan standardized coefficients variabel sebesar 3.847. Nilai signifikan variabel kurs adalah 0.002 , dimana nilai ini < 0.05 yang berarti variabel Kurs berpengaruh terhadap Indeks Harga Saham Industri Pertambangan. Variabel penelitian Suku Bunga SBI menunjukkan bahwa t-hitung sebesar 0.782 dengan standardized coefficients variabel sebesar -0.110 , karena nilai signifikan variabel Suku Bunga SBI adalah 0.439, dimana nilai ini > 0.05 yang berarti variabel Suku Bunga SBI tidak berpengaruh terhadap Indeks Harga Saham Industri Pertambangan. Variabel penelitian Harga Minyak Dunia menunjukkan bahwa t-hitung sebesar 4.724 dengan standardized coefficients variabel sebesar 0.659, karena nilai signifikan variabel Harga Minyak Dunia adalah 0.000 , dimana nilai ini < 0.05 yang berarti variabel Harga Minyak Dunia berpengaruh terhadap Indeks Harga Saham Industri Pertambangan. Variabel yang harga minyak dunia juga merupakan variabel yang paling berpengaruh terhadap indeks harga saham pertambangan.

\section{Koefisien Determinasi}

Tabel 7. Model Summary

\begin{tabular}{|l|r|r|r|r|}
\hline Model & R & R Square & Adjusted R Square & Std. Error of the Estimate \\
\hline 1 & $.643 \mathrm{a}$ & .414 & .339 & .7919655 \\
\hline
\end{tabular}

Sumber : Data diolah

Pada tabel diatas dapat dilihat bahwa nilai adjusted $\mathrm{R}$ Square sebesar 0.339. Hal ini berarti 34 persen indeks harga saham dapat dijelaskan oleh Inflasi, Kurs, Suku Bunga, dan Harga Minyak Dunia. Sisanya 66 persen dijelaskan oleh faktor lain yang tidak disertakan dalam variabel penelitian ini.

\section{SIMPULAN}

Berdasarkan hasil penelitian, maka dapat ditarik kesimpulan sebagai berikut:

1. Variabel Inflasi, Kurs, Suku Bunga, dan Harga Minyak Dunia secara simultan berpengaruh terhadap terhadap indeks harga saham industri pertambangan periode 2012-2015 yang terdaftar di Bursa Efek Indonesia.

2. Variabel kurs dan harga minyak dunia secara parsial berpengaruh terhadap terhadap indeks harga saham industri pertambangan periode 2012-2015 yang terdaftar di Bursa Efek Indonesia,

3. Besaran pengaruh Variabel Inflasi, Kurs, Suku Bunga, dan Harga Minyak Dunia terhadap indeks harga saham industri pertambangan periode $2012-2015$ yaitu sebesar $33.9 \%$, hal ini dilihat dari nilai Adjusted $R$ Square sebesar 0.339. Hal ini berarti 34\% variasi indeks harga saham industri pertambangan dapat dijelaskan oleh Inflasi, Kurs, Suku Bunga, dan Harga Minyak Dunia. Sisanya 66\% dijelaskan oleh faktor lain yang tidak disertakan dalam penelitian ini.

\section{DAFTAR PUSTAKA}

Adisetiawan dan Surono, 2011, Analisa Pengaruh Variabel-variabel Fundamental Terhadap Return Saham LQ45, Jurnal Ilmiah Universitas Batanghari Jambi, 11(2), 21-31

Adisetiawan, R., 2012, Kausalitas BI Rate, Inflasi, dan Indeks Harga Saham, Manajemen dan Bisnis, 11(2), 256-265

Adisetiawan, R., 2014, Keseimbangan Jangka Panjang antara Variabel Makro Ekonomi dengan Indeks Harga Saham, Trikonomika Journal, 10(2), 72-84 
Adisetiawan, R., 2017a, Globalisasi Pasar Modal Dunia dan Pengaruhnya Terhadap Pasar Modal Indonesia, Ekonomis: Journal of Economics and Business, 1(1), 10-17

Adisetiawan, R., 2017b, Simultan Jangka Panjang antara Fluktuasi Indeks Harga Saham, Tingkat Inflasi, Suku Bunga, dan Kurs IDR/USD Terhadap Return Saham Reksadana di Indonesia, Eksis: Jurnal Ilmiah Ekonomi dan Bisnis, 6(1), 5-17

Adisetiawan, R., 2018, Kausalitas Ekonomi Makro dan Global Terhadap Pasar Modal Indonesia, Ekonomis: Journal of Economics and Business, 2(1), 65-80

Bank Indonesia. 2007-2011. Indonesia Financial Statistik. Jakarta. www.bi.go.id.

Biro Pusat Statistik. 2007-2011. Tabel input-output Indonesia BPS. Jakarta. www.bps.co.id.

Bursa Efek Indonesia. 2007-2011. Indonesia Stock Exchange (IDX Monthly Statistic Report). www.idx.co.id.

Sugiyono. 2007. Metode Penelitian Bisnis. Bandung : Alfa. 